\title{
Pulmonary tuberculosis and lung cancer: simultaneous and sequential occurrence*
}

\author{
Tuberculose pulmonar e câncer de pulmão: ocorrência \\ simultânea ou sequencial
}

\author{
Denise Rossato Silva, Dirceu Felipe Valentini Junior, Alice Mânica Müller, \\ Carlos Podalirio Borges de Almeida, Paulo de Tarso Roth Dalcin
}

\begin{abstract}
Resumo
Objetivo: 0 câncer de pulmão (CP) é o tipo mais letal de câncer na população mundial e representa um importante problema de saúde pública. A tuberculose é outra causa significativa de morbidade e mortalidade, especialmente em países em desenvolvimento. A ocorrência de tuberculose pulmonar e CP no mesmo paciente, simultaneamente ou não, tem sido descrita em diversas séries de casos e estudos de caso-controle. 0 objetivo deste estudo foi descrever as características de pacientes com tuberculose e CP, com apresentação simultânea ou sequencial. Métodos: Estudo transversal, realizado através de revisão de prontuários. Resultados: Foram incluídos no estudo 24 pacientes com diagnósticos de tuberculose e CP no período entre 2009 e 2012. Os diagnósticos de tuberculose e CP ocorreram simultaneamente em 10 pacientes, enquanto a tuberculose foi diagnosticada antes do CP em 14. A mediana do tempo entre os diagnósticos foi de 5 anos (variação interquartil: 1-30 anos). Quatorze pacientes $(58,3 \%)$ eram do sexo masculino, $20(83,3 \%)$ eram brancos, e $22(91,7 \%)$ eram tabagistas ativos ou ex-tabagistas. 0 tipo histológico mais comum foi o adenocarcinoma, em 14 casos (58,3\%), seguido de carcinoma epidermoide, em $6(25,0 \%)$. Sete pacientes $(29,2 \%)$ já apresentavam metástases à distância no momento do diagnóstico; desses 7, 5 (71\%) tiveram o diagnóstico de CP e TB simultaneamente. Conclusões: Neste estudo, a maioria dos pacientes com tuberculose e CP eram tabagistas ou ex-fumantes e a tuberculose foi diagnosticada tanto antes quanto simultaneamente ao diagnóstico de CP. 0 carcinoma brônquico não pequenas células, em especial o adenocarcinoma, foi o tipo histológico mais comum.
\end{abstract}

Descritores: Tuberculose/diagnóstico; Neoplasias Pulmonares/diagnóstico; Comorbidade.

\begin{abstract}
Objective: Lung cancer (LC) is the leading cause of cancer-related death and represents a major public health problem worldwide. Another major cause of morbidity and mortality, especially in developing countries, is tuberculosis. The simultaneous or sequential occurrence of pulmonary tuberculosis and $\mathrm{LC}$ in the same patient has been reported in various case series and case-control studies. The objective of this study was to describe the characteristics of patients developing tuberculosis and LC, either simultaneously or sequentially. Methods: This was a cross-sectional study based on the review of medical charts. Results: The study involved 24 patients diagnosed with tuberculosis and LC between 2009 and 2012. The diagnoses of tuberculosis and LC occurred simultaneously in 10 patients, whereas tuberculosis was diagnosed prior to $\mathrm{LC}$ in 14 . The median time between the two diagnoses was 5 years (interquartile range: 1-30 years). Fourteen patients (58.3\%) were male, 20 $(83.3 \%)$ were White, and $22(91.7 \%)$ were smokers or former smokers. The most common histological type was adenocarcinoma, identified in 14 cases (58.3\%), followed by epidermoid carcinoma, identified in 6 (25.0\%). Seven patients $(29.2 \%)$ presented with distant metastases at diagnosis; of those 7 patients, $5(71 \%)$ were diagnosed with LC and tuberculosis simultaneously. Conclusions: In the present study, most of the patients with tuberculosis and $\mathrm{LC}$ were smokers or former smokers, and tuberculosis was diagnosed either before or simultaneously with LC. Non-small cell lung cancer, especially adenocarcinoma, was the most common histological type.
\end{abstract}

Keywords: Tuberculosis/diagnosis; Lung neoplasms/diagnosis; Comorbidity.

\footnotetext{
*Study carried out at the Federal University of Rio Grande do Sul School of Medicine, Porto Alegre, Brazil. Correspondence to: Denise Rossato Silva. Rua Ramiro Barcelos, 2350, Santa Cecília, CEP 90035-903, Porto Alegre, RS, Brasil. Tel. 5551 3359-8241.E-mail: denise.rossato@terra.com.br

Financial support: Dirceu Felipe Valentini Junior is the recipient of a Young Investigator Grant from the Conselho Nacional de Desenvolvimento Científico e Tecnológico (CNPq, National Council for Scientific and Technological Development).

Submitted: 1 April 2013. Accepted, after review: 3 June 2013.
} 


\section{Introduction}

Lung cancer (LC) is the most deadly type of cancer and represents a major public health problem worldwide. It is the leading cause of cancer-related death in Brazil and in the world, with 1.3 million deaths annually. ${ }^{(1)}$ Another major cause of morbidity and mortality, especially in developing countries, is tuberculosis. ${ }^{(2)}$

It has been suggested that inflammation and pulmonary fibrosis caused by tuberculosis can induce genetic damage, which can increase $\mathrm{LC}$ risk. ${ }^{(3-5)}$ The increased occurrence of $\mathrm{LC}$ in patients with tuberculosis can also be related to infection-induced immunosuppression. ${ }^{(6)}$ In contrast, cancer-induced or chemotherapy-induced immunosuppression can also lead to increased rates of tuberculosis reactivation in patients with solid tumors. ${ }^{(7)}$

The simultaneous or sequential occurrence of pulmonary tuberculosis and $\mathrm{LC}$ in the same patient has been reported in various case series and case-control studies. ${ }^{(8-13)}$ The association between these two diseases is important, since both are quite prevalent and have a major impact on public health. In addition, considering that one study ${ }^{(10)}$ demonstrated that the association between tuberculosis and $\mathrm{LC}$ varies in different ethnic groups and also in different regions, it is important to know the characteristics of these cases in Brazil. Therefore, the objective of this study was to describe the clinical characteristics of patients with pulmonary tuberculosis and LC.

\section{Methods}

This was a cross-sectional study, involving retrospective data collection, conducted in order to determine the characteristics of patients with tuberculosis and LC who were treated at the Hospital de Clínicas de Porto Alegre (HCPA, Porto Alegre Hospital de Clínicas), located in the city of Porto Alegre, southern Brazil. The HCPA is a general tertiary university hospital with 750 beds and approximately 30,000 hospitalizations annually. The HCPA Research Ethics Committee granted permission for access to patient records. A waiver of informed consent was obtained, and the researchers signed a confidentiality agreement.

The study involved patients diagnosed with tuberculosis and LC, either simultaneously or sequentially. We performed a search of the files of the pulmonology outpatient clinics for patients with tuberculosis and LC, and the electronic medical records of these patients were reviewed. A standardized form was completed for each patient included in the study. Demographic data and data relating to the diagnoses of tuberculosis and $\mathrm{LC}$ were collected, as were pulmonary function test results.

The diagnosis of pulmonary tuberculosis was based on consensus criteria ${ }^{(14)}$ : positive ZiehlNeelsen staining for AFB (two positive smears); positive Ziehl-Neelsen staining for AFB (a positive smear and a positive culture for Mycobacterium tuberculosis); positive Ziehl-Neelsen staining for AFB and radiological findings consistent with pulmonary tuberculosis; a single positive culture for M. tuberculosis; or epidemiological, clinical, and radiological findings consistent with pulmonary tuberculosis, associated with a favorable response to treatment with antituberculosis drugs. The diagnosis of LC was based on anatomopathological findings.

The diagnoses of $\mathrm{LC}$ and tuberculosis were classified by timing as follows: simultaneous-when the diagnoses of tuberculosis and LC occurred simultaneously or when the time between the two diagnoses was $<2$ months; sequential (LC first)-when tuberculosis was diagnosed $\geq 2$ after $\mathrm{LC}$ diagnosis and within 12 months of completion of LC treatment; sequential (tuberculosis first)-when $\mathrm{LC}$ is diagnosed $\geq 2$ months after tuberculosis diagnosis, indefinitely, because of the possibility of scar cancer. ${ }^{(10,15,16)}$

The data were entered into Microsoft Excel spreadsheets, after which they were processed and analyzed with the Statistical Package for the Social Sciences, version 18.0 (SPSS Inc., Chicago, IL, USA). We carried out a descriptive analysis of the study variables. Quantitative data are presented as mean \pm SD. Qualitative data are expressed as $n(\%)$.

\section{Results}

The study involved 24 patients diagnosed with tuberculosis and LC between 2009 and 2012. The principal characteristics of the patients are shown in Table 1. In 10 of the 24 patients, the diagnoses of tuberculosis and LC occurred simultaneously, whereas, in 14, tuberculosis was diagnosed before LC. The median time between the two diagnoses was 5 years (interquartile range: 1-30 years). 
Table 1 - Principal characteristics of the patients. ${ }^{a}$

\begin{tabular}{lc}
\hline Characteristic & Result \\
\hline Male gender & $14(58.3)$ \\
Age, years & $62.8 \pm 10.6$ \\
White race & $20(83.3)$ \\
Smoker & $11(45.8)$ \\
Former smoker & $11(45.8)$ \\
History of TB contact & $3(12.5)$ \\
Family history of LC & $3(12.5)$ \\
Time of diagnoses & $10(41.7)$ \\
$\quad$ TB and LC simultaneously & $14(58.3)$ \\
TB before LC & $0(0.0)$ \\
LC before TB & $14(58.3)$ \\
Type of LC & $6(25.0)$ \\
Adenocarcinoma & $4(16.7)$ \\
\hline
\end{tabular}

TB: tuberculosis; and LC: lung cancer. ${ }^{\text {VValues expressed as }}$ $n(\%)$, except where otherwise indicated. ${ }^{\text {b}}$ Value expressed as mean \pm SD.

Three patients (12.5\%) reported having had tuberculosis twice. The diagnosis of tuberculosis was established by the following methods: smear microscopy of spontaneous sputum, in 3 patients; culture of spontaneous sputum, in 2; smear microscopy of induced sputum, in 2; bronchoalveolar lavage (BAL) culture, in 2; PCR positivity for $M$. tuberculosis in BAL samples, in 4; and clinical and radiological findings consistent with tuberculosis, in 11.

Tuberculosis treatment was as follows: a regimen consisting of rifampin, isoniazid, and pyrazinamide, in 11 patients (45.8\%); and a regimen consisting of rifampin, isoniazid, pyrazinamide, and ethambutol, in 7 (29.2\%). In 6 patients (25.0\%), data on treatment regimen were either not provided or unavailable. Only 1 patient (4.2\%) reported noncompliance with tuberculosis treatment, 3 (12.5\%) died, and $16(66.7 \%)$ were discharged as cured. For 5 $(20.8 \%)$ of the patients, no treatment outcome data were available.

The mean age at $\mathrm{LC}$ diagnosis was 62.8 \pm 10.6 years. Of the 24 patients, 7 (29.2\%) presented with distant metastases at diagnosis; of those 7 patients, $71 \%$ were diagnosed with LC and tuberculosis simultaneously. The following LC treatments were performed: radiotherapy alone, in 6 patients (25.0\%); chemotherapy and radiotherapy, in 4 (16.7\%); surgery alone, in $3(12.5 \%)$; chemotherapy alone, $2(8.3 \%)$; surgery and radiotherapy, in 2 (8.3\%); surgery and chemotherapy, in 2 (8.3\%); and supportive treatment alone, in 5 (20.8\%).

\section{Discussion}

In this study, we described the characteristics of 24 patients developing tuberculosis and LC, either simultaneously or sequentially. Tuberculosis was diagnosed before $\mathrm{LC}$ in most of the patients, and in none of the cases was LC diagnosed before tuberculosis. Non-small cell lung cancer, especially adenocarcinoma, was the most common histological type.

The coexistence of pulmonary tuberculosis and LC was first described in 1810, and it was demonstrated histologically a few years later. ${ }^{(9)}$ Since then, several studies on this association have been published, most of which are case series and case-control studies..$^{(8-13)}$ However, it has always been questioned whether this association was casual or whether it could be explained by a plausible biological mechanism. One hypothesis would be that inflammation associated with infections can contribute to carcinogenesis. ${ }^{(4)}$ Reactive oxygen or nitrogen species produced by activated neutrophils can bind to the DNA, inducing genetic damage and neoplastic transformation. ${ }^{(17,18)} \mathrm{In}$ fact, it has been shown that alterations of the fragile histidine triad gene might be involved in lung carcinogenesis in patients with chronic pulmonary tuberculosis. ${ }^{(19-21)}$ In addition, during tissue repair, there is increased cell proliferation and angiogenesis, and the epithelium is more prone to metaplasia. Furthermore, carcinogens concentrate preferentially in hyperactive areas to induce neoplastic changes. ${ }^{(22,23)}$

The cases described here are similar to those reported in previous studies. ${ }^{(8-13)}$ Adenocarcinoma was the most common histological type in our case series. In a meta-analysis ${ }^{(10)}$ of 37 case-control studies and 4 cohort studies, the association between tuberculosis and LC was significant for adenocarcinoma (relative risk $=1.6$ ), but not for epidermoid carcinoma or small cell carcinoma. In a case series of LC in Japan, ${ }^{(24)}$ adenocarcinoma was also the most common cancer. Another study ${ }^{(9)}$ demonstrated that all scar carcinomas were adenocarcinomas, and that, even in cases in which there was no proximity between the scar and the neoplasm, adenocarcinoma was the most common histological type. 
The vast majority of the patients described here were smokers or former smokers. Despite the cumulative effects of tobacco as a carcinogen, the relationship between pulmonary tuberculosis and LC persists even after control for smoking, with cancer risk being 2.5-fold higher among patients with tuberculosis. ${ }^{(6,8,25)} \mathrm{A}$ meta-analysis ${ }^{(10)}$ corroborated this evidence, showing that the association between tuberculosis and $\mathrm{LC}$ was not due to the effects of smoking, because, when considering only nonsmoking patients, there was a 1.78-fold increase in LC risk among patients with tuberculosis. That same metaanalysis demonstrated that the association between tuberculosis and $\mathrm{LC}$ was not due to the time since diagnosis of tuberculosis. Because the initial symptoms of $\mathrm{LC}$ can be mistaken for the symptoms of pulmonary tuberculosis, that analysis was restricted to studies in which tuberculosis was diagnosed more than 1 year before cancer, in order to minimize this bias. The studies were grouped by time between the two diagnoses (1-5, 6-10, 11-20, and more than 20 years). The increase in cancer risk was higher in the first 5 years after tuberculosis; diagnosis; however, the risk remained 1.99-fold higher among those for whom the time between the diagnoses was more than 20 years. This was true in our sample as well, given that the median time between the diagnoses of tuberculosis and $\mathrm{LC}$ was 5 years (interquartile range: 1-30 years). Another, more recent study ${ }^{(11)}$ showed that $\mathrm{LC}$ risk was highest in the 2-year window after tuberculosis diagnosis $(\mathrm{OR}=5.01)$ but remained elevated even 2 years after diagnosis $(\mathrm{OR}=1.53)$.

Approximately 30\% of the patients presented with distant metastases at $\mathrm{LC}$ diagnosis. Of those, $71 \%$ were diagnosed with $\mathrm{LC}$ and tuberculosis simultaneously. Another case series found that $50 \%$ of the patients had stage IV LC. ${ }^{(24)}$ Because the initial symptoms of these two diseases are similar, it should be considered that there can be a delay in the diagnosis of either condition and, consequently, patients can present with either LC or tuberculosis at a more advanced stage. ${ }^{(26)}$

In none of our reported cases was LC diagnosed before pulmonary tuberculosis. In contrast, in a recent, retrospective case-control study(15) involving 36 patients with LC, 10 (27.8\%) were diagnosed with tuberculosis and cancer concomitantly, whereas 26 (72.2\%) were diagnosed with tuberculosis after being diagnosed with cancer. In a case series conducted in Japan, ${ }^{(24)}$ the diagnoses were concomitant in 6 patients, tuberculosis was diagnosed before $\mathrm{LC}$ in 5 cases, and $\mathrm{LC}$ was diagnosed before tuberculosis in the remaining 5 . It is possible that tuberculosis was diagnosed before $\mathrm{LC}$ more frequently because of a reverse causality bias, i.e., an occult cancer can reduce immunity and lead to reactivation of latent tuberculosis. Therefore, tuberculosis can present clinically before $\mathrm{LC} .^{(16,19)}$

Our study has limitations that need to be considered. The major one is that the cases were identified retrospectively on the basis of a search of the files of the specialized outpatient clinics at our hospital. Retrospective studies are at risk of selection bias (cases lost to follow-up) and measurement bias (data obtained from medical records). We should also consider the Berkson bias, in which patients with an index diagnosis are more likely to be diagnosed with another disease than are those without an index diagnosis. For instance, patients with tuberculosis, at follow-up chest X-ray, are more prone to be diagnosed with cancer than are those not diagnosed with tuberculosis. ${ }^{(27)}$ Nevertheless, because the occurrence of tuberculosis and LC, either simultaneously or not, may have different characteristics according to ethnic group and region, ${ }^{(10)}$ it is relevant that cases identified locally be described. In addition, the importance of these cases lies in the fact that patients diagnosed with tuberculosis should be advised to avoid lung carcinogens, such as tobacco smoking, as much as possible, since these agents contribute to a substantial increase in $\mathrm{LC}$ risk.

In conclusion, the present study demonstrated that most of the patients with tuberculosis and LC were smokers, and that tuberculosis was diagnosed either before or simultaneously with LC. Non-small cell lung cancer, especially adenocarcinoma, was the most common histological type.

\section{References}

1. INCA Instituto Nacional do Câncer [homepage on the Internet]. Rio de Janeiro: INCA. [cited 2013 Apr 1]. Pulmão. Available from: www.inca.gov.br

2. World Health Organization [homepage on the Internet]. Geneva: World Health Organization. [cited 2013 Apr 1]. WHO REPORT 2009 Global Tuberculosis Control - Epidemiology, Strategy, Financing. [Adobe Acrobat document, 86p.]. Available from: http://whqlibdoc.who. int/publications/2009/9789241563802_eng_doc.pdf

3. Ballaz S, Mulshine JL. The potential contributions of chronic inflammation to lung carcinogenesis. Clin Lung 
Cancer. 2003;5(1):46-62. http://dx.doi.org/10.3816/ CLC.2003.n.021 PMid:14596704

4. Coussens LM, Werb Z. Inflammation and cancer. Nature. 2002;420(6917):860-7. http://dx.doi.org/10.1038/ nature01322 PMid:12490959 PMCid:2803035

5. Engels EA. Inflammation in the development of lung cancer: epidemiological evidence. Expert Rev Anticancer Ther. 2008;8(4):605-15. http://dx.doi. org/10.1586/14737140.8.4.605 PMid:18402527

6. Rybacka-Chabros B, Mańdziuk S, Berger-Lukasiewicz A, Dańko-Mrozińska M, Milanowski J. The coexistence of tuberculosis infection and lung cancer in patients treated in pulmonary department of Medical Academy in Lublin during last ten years (1990-2000). Folia Histochem Cytobiol. 2001;39 Suppl 2:73-4. PMid:11820634

7. Kim HR, Hwang SS, Ro YK, Jeon CH, Ha DY, Park $\mathrm{SJ}$, et al. Solid-organ malignancy as a risk factor for tuberculosis. Respirology. 2008;13(3):413-9. http://dx.doi. org/10.1111/j.1440-1843.2008.01282.x PMid:18399865

8. Brenner AV, Wang Z, Kleinerman RA, Wang L, Zhang $\mathrm{S}$, Metayer $\mathrm{C}$, et al. Previous pulmonary diseases and risk of lung cancer in Gansu Province, China. Int J Epidemiol. 2001;30(1):118-24. http://dx.doi.org/10.1093/ ije/30.1.118 PMid:11171871

9. Dacosta NA, Kinare SG. Association of lung carcinoma and tuberculosis. J Postgrad Med. 1991;37(4):185-9. PMid:1841965

10. Liang HY, Li XL, Yu XS, Guan P, Yin ZH, He QC, et al. Facts and fiction of the relationship between preexisting tuberculosis and lung cancer risk: a systematic review. Int J Cancer. 2009;125(12):2936-44. http://dx.doi. org/10.1002/ijc.24636 PMid:19521963

11. Shiels MS, Albanes D, Virtamo J, Engels EA. Increased risk of lung cancer in men with tuberculosis in the alpha-tocopherol, beta-carotene cancer prevention study. Cancer Epidemiol Biomarkers Prev. 2011;20(4):672-8. http://dx.doi.org/10.1158/1055-9965.EPl-10-1166 PMid:21335509 PMCid:3076700

12. Wu CY, Hu HY, Pu CY, Huang N, Shen HC, Li CP, et al. Pulmonary tuberculosis increases the risk of lung cancer: a population-based cohort study. Cancer. 2011;117(3):61824. http://dx.doi.org/10.1002/cncr.25616 PMid:20886634

13. Yu YH, Liao CC, Hsu WH, Chen HJ, Liao WC, Muo CH, et al. Increased lung cancer risk among patients with pulmonary tuberculosis: a population cohort study. J Thorac Oncol. 2011;6(1):32-7. http://dx.doi.org/10.1097/ JT0.0b013e3181 fb4fcc PMid:21150470

14. Conde MB, Melo FA, Marques AM, Cardoso NC, Pinheiro VG, Dalcin Pde T, et al. 111 Brazilian Thoracic Association Guidelines on tuberculosis. J Bras Pneumol. 2009;35(10):1018-48. PMid:19918635

15. Cha SI, Shin KM, Lee JW, Lee SY, Kim CH, Park JY, et al. The clinical course of respiratory tuberculosis in lung cancer patients. Int J Tuberc Lung Dis. 2009;13(8):1002-7. PMid:19723381
16. Libshitz HI, Pannu HK, Elting LS, Cooksley CD. Tuberculosis in cancer patients: an update. J Thorac Imaging. 1997;12(1):41-6. http://dx.doi.org/10.1097/00005382199701000-00006 PMid:8989758

17. Lin WW, Karin M. A cytokine-mediated link between innate immunity, inflammation, and cancer. J Clin Invest. 2007;117(5):1175-83. http://dx.doi.org/10.1172/JCl31537 PMid:17476347 PMCid:1857251

18. Rosin MP, Anwar WA, Ward AJ. Inflammation, chromosomal instability, and cancer: the schistosomiasis model. Cancer Res. 1994;54(7 Suppl):1929s-1933s. PMid:8137314

19. Nalbandian A, Yan BS, Pichugin A, Bronson RT, Kramnik 1. Lung carcinogenesis induced by chronic tuberculosis infection: the experimental model and genetic control. Oncogene. 2009;28(17):1928-38. http://dx.doi.org/10.1038/onc.2009.32 PMid:19330024

20. Song L, Yan W, Deng M, Song S, Zhang J, Zhao T. Aberrations in the fragile histidine triad(FHIT) gene may be involved in lung carcinogenesis in patients with chronic pulmonary tuberculosis. Tumour Biol. 2004;25(5-6):270-5. http://dx.doi.org/10.1159/000081391 PMid: 15627891

21. Song L, Yan W, Zhao T, Deng M, Song S, Zhang J, et al. Mycobacterium tuberculosis infection and FHIT gene alterations in lung cancer. Cancer Lett. 2005;219(2):15562. http://dx.doi.org/10.1016/j.canlet.2004.06.036 PMid:15723714

22. Dheda K, Booth H, Huggett JF, Johnson MA, Zumla A, Rook GA. Lung remodeling in pulmonary tuberculosis. J Infect Dis. 2005;192(7):1201-9. http://dx.doi. org/10.1086/444545 PMid:16136463

23. Limas C, Japaze H, Garcia-Bunuel R. "Scar" carcinoma of the lung. Chest. 1971;59(2):219-22. http://dx.doi. org/10.1378/chest.59.2.219 PMid:4322551

24. Watanabe A, Tokue Y, Takahashi H, Sato K, Nukiwa T, Honda Y, et al. Management of mycobacteriosis in general hospital without isolation ward for tuberculosis patients. Clinical study on pulmonary tuberculosis associated with lung cancer patients [Article in Japanese]. Kekkaku. 1999;74(2):157-62. PMid:10191612

25. Le CH, Ko YC, Cheng LS, Lin YC, Lin HJ, Huang MS, et al. The heterogeneity in risk factors of lung cancer and the difference of histologic distribution between genders in Taiwan. Cancer Causes Control. 2001;12(4):289300. http://dx.doi.org/10.1023/A:1011270521900

26. Singh VK, Chandra S, Kumar S, Pangtey G, Mohan A, Guleria R. A common medical error: lung cancer misdiagnosed as sputum negative tuberculosis. Asian Pac J Cancer Prev. 2009;10(3):335-8. PMid:19640168

27. Fontham ET, Correa P, Reynolds P, Wu-Williams A, Buffler PA, Greenberg RS, et al. Environmental tobacco smoke and lung cancer in nonsmoking women. A multicenter study. JAMA. 1994;271(22):1752-9. Erratum in: JAMA 1994;272(20):1578. http://dx.doi. org/10.1001/jama.1994.03510460044031 PMid:8196118 


\section{About the Authors}

Denise Rossato Silva

Adjunct Professor of Pulmonology. Federal University of Rio Grande do Sul School of Medicine, Porto Alegre, Brazil.

\section{Dirceu Felipe Valentini Junior}

Medical Student. Federal University of Rio Grande do Sul School of Medicine, Porto Alegre, Brazil.

\section{Alice Mânica Müller}

Doctoral Student. Graduate Program in Pulmonology, Federal University of Rio Grande do Sul School of Medicine, Porto Alegre, Brazil.

Carlos Podalirio Borges de Almeida

Master's Student. Graduate Program in Pulmonology, Federal University of Rio Grande do Sul School of Medicine, Porto Alegre, Brazil.

\section{Paulo de Tarso Roth Dalcin}

Associate Professor of Pulmonology. Federal University of Rio Grande do Sul School of Medicine, Porto Alegre, Brazil. 